\title{
Using Clickers for Deliberate Practice in Five Large Science Courses
}

\author{
By Linda C. Hodges, Eric C. Anderson, Tara S. Carpenter, Lili Cui, Elizabeth A. Feeser, \\ and Tiffany Malinky Gierasch
}

Clickers are often used as an active learning tool in face-to-face classes to enhance student engagement and assess student learning. In this article we share the variety of ways that we use clicker questions to promote deliberate practice in large science courses. Deliberate practice is the use of specifically structured exercises that develop the skills and habits of mind essential to improve performance. We use clickers across five different courses in biology, chemistry, and physics at a midsize public research university to develop students' abilities in scientific reasoning and problem solving. We gathered students' views of our practices using the Classroom Response System Perceptions (CRiSP) Questionnaire. Even given the differences in our approaches, the majority of the 1,614 students who responded reported that our clicker questions enhanced their motivation, attention, engagement, and participation in class. Students recognized that we used clickers to provide practice and feedback, addressing their learning needs in real time. Students were less positive about clicker questions making class more enjoyable, and a third of students reported answering without really understanding. These responses may reflect that clickers require students to test themselves before the exam-a critical, though sometimes discomfiting, step to learning.
1 popular tool to facilitate active learning is a classroom response system, often referred to as a clicker. With this tool, students respond to instructors' questions by clicking on their answer using a remote device (clicker) that communicates with the classroom computer. An anonymous, quantitative compilation of responses can be displayed that provides feedback to both instructors and students (reviewed in Bruff, 2009; Caldwell, 2007). Recent metaanalyses have synthesized results from numerous studies on the effects of clicker questions on student learning (Castillo-Manzano, CastroNuño, López-Valpuesta, Sanz-Díaz, \& Yñiguez, 2016; Chien, Chang, \& Chang, 2016; Hunsu, Adesope, \& Bayley, 2016). At a minimum, engaging students in answering clicker questions in class promotes their sense of self-efficacy (Hunsu et al., 2016), that is, the belief in their ability to do a certain task. Clicker questions also may aid conceptual learning (Chien et al., 2016; Hunsu et al., 2016), especially when used in peer-aided learning approaches (Liu et al., 2016). It is important to note that clickers used in other ways also enhance learning compared with lecture or verbal question-answer formats alone, presumably by providing students with immediate feedback in a nonintimidating way (Chien et al., 2016).

MacArthur (2013) advocated for studies that focused on understanding how instructors use clickers as a way to stimulate their more wide- spread adoption. Few studies have compared clicker use across science disciplines at an institution (an exception is Goacher, Moore, Sanchez, Schupp, \& Tong, 2015). In this article, we share cross-disciplinary perspectives on ways to use clickers to provide students with deliberate practice in large science classes, focusing on how we integrate them into class, plan questions, and provide feedback. We also share students' perceptions of clickers used in this way gathered using a validated survey, the Classroom Response System Perceptions (CRiSP) Questionnaire (Richardson, Dunn, McDonald, \& Oprescu, 2015).

\section{Clickers for deliberate practice}

Deliberate practice is a distinct approach to learning complex skills, such as those required in musical or athletic performance, and has been shown to be one key factor in the development of expertise (Ericsson, Krampe, \& Tesch-Römer, 1993). Science education researchers propose the use of deliberate practice to develop expertise in science as well (Wieman, \& Gilbert, 2015). Elements of deliberate practice (Ericsson et al., 1993) include the following:

- cultivating motivation for the task,

- building on prior knowledge to push to the next level,

- receiving immediate informative feedback, and

- repeating the key learning task. 
Clickers can enable instructors to address all these elements in a large class. For example, asking questions this way can create a supportive, game-like atmosphere in a large class that helps students develop a sense of self-efficacy that can enhance motivation (Schunk, 1991). Clicker questions can elicit students' prior knowledge - including exposing and addressing their misconceptionsand then move students to deeper levels of understanding. Ideally questions circle back and reinforce major concepts and skills. Instructors' feedback to students needs to go beyond the right/wrong display to encourage them to reflect, analyze, and self-evaluate - characteristics of expert learners. Thus, the real keys to using clickers for meaningful deliberate practice are the kinds of questions asked and the ways answers are debriefed.

The authors teach large introductory science courses at a midsize public research university and use clickers to engage students in deliberate practice in class. When clickers are used only to promote students' attention or attendance or without connecting their use to course goals, students may not enjoy using them and may not think they are worth the cost (Meehan \& Salmun, 2016). Our approaches, however, engage students in significant question-answer opportunities, essentially allowing a Socratic dialogue in large-lecture settings. Such approaches are similar to those found to be successful in promoting learning in a first-year physics course (Deslauriers, Schelew, \& Wieman, 2011).

\section{How we use clickers in class}

We weave clicker questions throughout our class sessions to engage groups of students in practicing essential concepts and skills (see Table 1). For example, one author teaches the introductory biology course for majors. In each session, after she presents course concepts, she uses clickers to ask complex application questions that students discuss with other students. She stimulates students' involvement during group discussions by letting them know that they may be called on to explain a question.

Two authors use clicker questions both for group discussion questions and for reading quizzes in chemistry courses (Hodges et al., 2015). They teach the general chemistry and the organic chemistry sequences, respectively-courses for science, engineering, and preprofessional majors. Each instructor assigns reading and web-based problems prior to class so that students come prepared with basic knowledge of the day's topic. Students are held accountable for this preparation by taking reading quizzes at the beginning of class. The remainder of class is used for group discussion questions.

Two other authors teach the two introductory sequences in physics, one for physical sciences or engineering majors and one for life sciences majors. Students read and take an online quiz before class to prepare them for class activities. The instructors spend less than half the session providing overviews of concepts, example problems, and problem-solving strategies; the rest is spent on clicker questions. They ask students to think or write their answers to questions first individually and then discuss with others around them-asking students to extend their group until they find a divergent viewpoint.

During clicker-question discussions in all our classes, we (and in some cases our undergraduate

\section{TABLE 1}

\section{Logistics of clicker question use.}

\begin{tabular}{|l|l|l|l|l|}
\hline $\begin{array}{l}\text { Course name, enrollments, class } \\
\text { length }\end{array}$ & $\begin{array}{l}\text { As reading } \\
\text { quiz }\end{array}$ & $\begin{array}{l}\text { For group } \\
\text { discussion }\end{array}$ & $\begin{array}{l}\text { No. during } \\
\text { class }\end{array}$ & Contribution to grade \\
\hline $\begin{array}{l}\text { Foundations of Biology, } \\
300 \text { students, } 75 \text { minutes }\end{array}$ & No & Yes & $10-12$ & $\begin{array}{l}10 \% \\
\text { Participation and correctness }\end{array}$ \\
\hline $\begin{array}{l}\text { General Chemistry, } \\
300 \text { students, } 50 \text { minutes }\end{array}$ & Yes & Yes & 10 & $\begin{array}{l}10 \% \\
\text { Reading quiz: correctness } \\
\text { Discussion questions: participation } \\
\text { and correctness }\end{array}$ \\
\hline $\begin{array}{l}\text { Organic Chemistry } \\
200-250 \text { students, } 50 \text { minutes }\end{array}$ & Yes & Yes & 10 & $\begin{array}{l}10 \% \\
\text { Reading quiz: correctness } \\
\text { Discussion questions: participation } \\
\text { and correctness }\end{array}$ \\
\hline $\begin{array}{l}\text { Introductory Physics, } \\
150-300 \text { students, } 50 \text { minutes }\end{array}$ & No & Yes & $3-7$ & $\begin{array}{l}5 \% \\
\text { Participation only }\end{array}$ \\
\hline
\end{tabular}

Note. Clickers were purchased from Turning Technologies. 
learning assistants) move through the lecture hall, answering questions and encouraging conversation. After a designated time, we display the composite histogram of responses. We each take a slightly different approach to debriefing the answers, as we discuss in a later section.

\section{How we grade clicker questions}

As others have noted, assigning points to clicker questions encourages students to take them seriously (Freeman et al., 2007; Jones, Crandall, Vogler, \& Robinson, 2013). Individual clicker question responses can be linked to student identity in the learning management system (LMS), allowing us to factor them into grades. Participation points motivate students to attempt the questions and emphasize the value in learning from mistakes. For example, in physics the two authors often pose questions designed to draw out intuitive ideas or tenacious misconceptions, and grading on participation encourages students to be candid. The biology instructor stimulates students' cognitive engagement by grading one randomly selected question each day for correctness. The two chemistry instructors score reading quiz questions for correctness, but because discussion questions require an additional level of understanding, students earn half credit for trying them.

\section{How we design clicker questions}

In introductory biology, the author uses a combination of clicker questions and open-ended activities to facilitate deliberate practice of essential skills. In the unit on nucleic acids, for example, students explore common confusions about the nature and structure of DNA and RNA through clicker questions on nucleic acid composition. In the unit on genes, students use a figure that illustrates a biochemical pathway to complete a chart indicating the phenotypes of various mutants. Students then answer clicker questions using only their chart, giving students practice in making connections between various representations of information. She uses true/ false clicker questions to address student misconceptions by linking true statements with incorrect conclusions. Students thus must apply specific criteria to recognize why the true statement does not cause the given outcome.

Likewise, the organic chemistry instructor designs some discussion questions to expose students' misconceptions, deliberately leading them down a common novice thinker's path. The surprise when the common answer is not correct creates a teachable moment. She also pushes students to the next level by asking sequenced questions on a topic, with questions becoming progressively more challenging by requiring students to take into account more selection criteria. For example, relative acidity provides an important model for understanding some chemical reactivity. Reading quiz questions on this topic ask about single concept trends, whereas discussion quiz questions ask students to use multiple concepts/trends.

Similarly, in general chemistry, developing correct mental models (e.g., of the relationship of atoms to molecules) is key to understanding chemical behavior. The author uses reading quiz questions to elicit students' prior knowledge on such topics and then asks them to build on and integrate those ideas in more demanding discussion questions. At least one question per class requires students to determine what information is necessary, missing, or superfluous to solving a problem, simulating real-world, problemsolving processes.

Effective problem solving in physics requires the ability to represent a problem in multiple ways- words, graphs or specialized diagrams, and equations. One physics instructor, for example, uses clicker questions to lead students through a pictorial analysis of forces to answer questions such as: "How fast does a skateboarder need to enter a loopthe-loop in order not to fall off at the top?" The other author fosters physics students' understanding of properties of electricity by asking clicker questions that require students to represent and analyze complex resistor circuits. By giving students deliberate practice in creating and connecting representations of problems to mathematical analysis, both instructors provide students with a check on reasoning, suggest a path to a mathematical solution, and promote more expert-like problem solving.

\section{How we debrief clicker questions}

Providing students with informative feedback is an important part of deliberate practice. We cultivate students' critical thinking and selfmonitoring skills during question debriefs. In introductory biology, for example, the author provides students with a framework for solving complex problems by using a standard format when reviewing clicker questions. She asks students to unpack each response methodically by explaining each answer, stating whether each option is true or false and whether it is relevant to the question. She then asks them to revise false statements to make them true. This system encourages students to review prior knowledge and take a reflective, analytical approach to problem solving.

In general chemistry, the author reviews discussion questions that a majority of her class answer incorrectly or if she observes misconceptions or illogical thinking in a significant number of students. For other questions, she gives a quick 
reminder of the thought process behind the problem. She points out similarities in concepts across apparently unrelated problems and primes students to look for similarities and differences when practicing problems on their own. She prompts them to determine not only why the correct answer is right, but also why the incorrect answer is wrong to develop their metacognition.

When students are fairly evenly divided on their responses to a question in organic chemistry, the author uses a peer-instruction (PI) approach by having them discuss and vote again (Mazur, 1997). When most students pick the wrong answer, she asks them why they picked the answer to try to reveal the origin of the mistake. She induces students to question their assumptions and reasoning by asking why each answer is correct.

In physics, one author invites students to share ideas or reasoning with the class, and he follows up with a brief description and evaluation of the most common responses and reasoning. He emphasizes the importance of rerepresenting information as a way to develop problem-solving skills. The other author debriefs questions that a majority of students answer correctly by having volunteers explain why choices are correct, assisting them as needed. If the majority of students miss the question, she gives some guidance and asks them to revote. She often uses the questions to segue to more discussion or a demonstration to achieve deeper understanding.
Calling on students when debriefing questions in large classes poses two problems - who and how. We call on volunteers to explain answers, choosing different people if at all possible. The biology instructor, however, also calls on students randomly, choosing from names on index cards. This practice encourages students to engage with the question during discussion. Although random calling can seem intimidating, studies have shown that it can boost students' confidence in speaking (Dallimore, Hertenstein, \& Platt, 2013) and reduce potential gender bias in participation (Eddy, Brownell, \& Wenderoth, 2014). Most of us repeat individual responses so that the whole class can hear and so that we can correct minor errors or

\section{TABLE 2}

Average student responses on questions on "impact on learning" across five science courses $(N=1,614)$.

\begin{tabular}{|l|l|l|l|}
\hline Questions & $\begin{array}{l}\text { \% } \\
\text { Agreement }\end{array}$ & $\begin{array}{l}\% \\
\text { Neutral }\end{array}$ & $\begin{array}{l}\text { \% } \\
\text { Disagreement }\end{array}$ \\
\hline 1.I would recommend that this instructor continue to use clickers. & 82.3 & 10.3 & 7.5 \\
\hline 2. The use of clickers helped increase the overall value of this course. & 69.4 & 19.0 & 11.7 \\
\hline 3. Using clickers in lectures wasted too much time in this course. & 12.8 & 17.2 & 69.9 \\
\hline $\begin{array}{l}\text { 4. I found this method of interaction (clickers) between the students and this } \\
\text { instructor effective. }\end{array}$ & 73.2 & 15.9 & 10.9 \\
\hline $\begin{array}{l}\text { 5. Using clickers in this course helped me get instant feedback on what I knew } \\
\text { and didn't know. }\end{array}$ & 82.3 & 9.9 & 7.8 \\
\hline $\begin{array}{l}\text { 6. The use of clicker questions helped increase my awareness of my peers' } \\
\text { opinions and attitudes. }\end{array}$ & 70.7 & 18.3 & 11.0 \\
\hline $\begin{array}{l}\text { 7. Using clicker questions in this course allowed me to better understand key } \\
\text { concepts. }\end{array}$ & 69.1 & 17.2 & 13.7 \\
\hline $\begin{array}{l}\text { 8. This instructor used the results from clicker questions to gauge class } \\
\text { understanding and reinforce material that was not understood. }\end{array}$ & 75.1 & 14.1 & 10.8 \\
\hline 9. Using clicker questions enhanced my learning of this subject. & 68.8 & 18.6 & 12.6 \\
\hline $\begin{array}{l}\text { 10.I believe that using clicker questions provided me with more control over my } \\
\text { learning than in courses that do not use clickers. }\end{array}$ & 54.7 & 25.8 & 19.5 \\
\hline $\begin{array}{l}\text { 11. Using clicker questions in this course helped me think more deeply about } \\
\text { course materials. }\end{array}$ & 61.7 & 21.5 & 16.8 \\
\hline 12. I often voted for the right answer without really understanding. & 33.2 & 25.5 & 41.3 \\
\hline Added question & 80.5 & 12.0 & 7.5 \\
\hline 13. Answering clicker questions helped me practice course content. & & \\
\hline
\end{tabular}

Note. Percentage of agreement (or disagreement) reflects the average of the sums of both strongly agree and agree responses (or strongly disagree and disagree responses). Responses to Questions 3 and 12 were reversed when comparing the positive responses for all classes via one-way analysis of variance. 
omissions. The biology instructor passes around several handheld microphones so that the student voice is affirmed.

\section{Methodology}

We gathered students' feedback on our approaches using the CRiSP questionnaire (Richardson et al., 2015). The 26-item survey asks students questions related to three categories: impact on learning (12 questions), effect on engagement (10 questions), and clicker usability (4 questions). Given our goal of providing students with deliberate practice, we added a question at the end asking students about the use of clickers to practice content (Tables 2 and 3). Students answered using a five-point Likert scale.

We administered the survey near the end of fall semester 2016 in the first courses in the sequences for introductory biology, introductory chemistry, organic chemistry, and introductory physics (the course for life science majors and the one for engineering majors). We collected responses using our institution's LMS and allocated a small amount of extra credit to incentivize participation. The LMS recorded students' participation without connecting responses to each individual so that student responses were anonymous.

\section{Results}

To compare results across courses, we added the percentage of students' positive responses (strongly agree, agree) for each instructor on the questions that fit the categories of "impact on learning" and "student engagement" and compared those to the neutral responses and the sum of negative responses (disagree, strongly disagree) on the same questions (Tables 2 and 3). Students did not note any difficulties in using our clicker system, so we did not explore those questions further.

A total of 1,614 students took the survey (some students took the survey in multiple courses) with overall response rates of $77 \%$ to $84 \%$. Given the sufficiently large sample size, the sample proportion is approximately normally distributed with the mean equal to true proportion. One-way analysis of variance of the sums of positive responses (likewise sums of negatives) showed no statistically significant differences between results from different courses. Although there were some differences across questions, student responses across courses were quite similar (Figures 1 and 2).

Students were largely positive about the impact of clickers on their learning with a few exceptions, discussed next. A large majority of students (on average $70 \%$ or more) agreed that clicker questions

- should continue to be used by the instructor,

- provided an effective method of interaction,

- helped them get instant feedback on their understanding,

- increased their awareness of others' opinions, and

- were used by the instructor to assess class understanding and reinforce material.

In addition, $80 \%$ of students agreed that answering clicker questions

\section{TABLE 3}

Average student responses on questions on "engagement" across five science courses $(N=1,614)$.

\begin{tabular}{|c|c|c|c|}
\hline Questions & $\begin{array}{l}\% \\
\text { Agreement }\end{array}$ & $\begin{array}{l}\% \\
\text { Neutral }\end{array}$ & $\begin{array}{l}\% \\
\text { Disagreement }\end{array}$ \\
\hline 1. Clickers used in this course motivated me to learn. & 72.0 & 15.8 & 12.2 \\
\hline 2. Using clickers in this course made me more confident to participate in class. & 48.4 & 28.8 & 22.7 \\
\hline 3. I used clickers most times when they were used in this course. & 90.3 & 6.8 & 2.9 \\
\hline 4. Clickers increased the frequency of my direct participation in this course. & 79.2 & 12.4 & 8.5 \\
\hline 5. The use of clickers in this course helped me to be active in class. & 78.4 & 13.3 & 8.4 \\
\hline 6. Using clickers in this course helped me pay more attention in class. & 78.0 & 11.9 & 10.1 \\
\hline 7. Using clickers has helped my concentration levels in lectures in this course. & 73.0 & 12.7 & 14.3 \\
\hline 8. Using clickers has encouraged me to attend lectures in this course. & 86.5 & 8.1 & 5.4 \\
\hline 9. Using clickers has increased my enjoyment of lectures in this course. & 37.8 & 39.8 & 22.4 \\
\hline $\begin{array}{l}\text { 10. Other students could not see my answers when using clickers in this course, } \\
\text { which encouraged me to be an active participant in class. }\end{array}$ & 46.2 & 36.5 & 17.3 \\
\hline
\end{tabular}

Note. Percentage of agreement (or disagreement) reflects the average of the sum of both strongly agree and agree responses (or strongly disagree and disagree responses). 
helped them practice course content, a major goal of our deliberate practice approach.

Students were also generally positive on questions about clickers enhancing their engagement, though there were some interesting exceptions to this that we discuss. More than $90 \%$ of students claimed to use clickers regularly in class. A large majority of students (on average $70 \%$ or more) agreed that using clickers

- motivated them to learn,

- increased their participation in the course,

- helped them to be active in class,

- helped them pay more attention in class,

- helped them concentrate in lecture, and

- encouraged them to attend lectures.

Students were more neutral about whether clickers increased their enjoyment of lectures and about whether the anonymity of clickers contributed to their active participation in class. In addition, student responses were almost equally divided among agreeing, being neutral, and disagreeing on the question "I often voted for the right answer without really understanding." Less than half of students agreed that clickers made them more confident to participate in class.

\section{Discussion and implications}

Probing students' understanding via question-answer is perhaps the oldest, and most effective, active learning approach. Clickers and similar technologies allow a simulation of Socratic teaching even in large classes. Their ease and effectiveness of use means that instructors can use clicker questions in any number of ways, from a whole course format such as PI to more modest, incremental exercises that engage students in critical thinking. We find that clicker questioning helps

\section{FIGURE 1}

\section{Range in percentages of students who agree or strongly agree on "impact of learning" questions across five courses $(N=1,614)$. Note that questions 3 and 12 are negatively worded.}

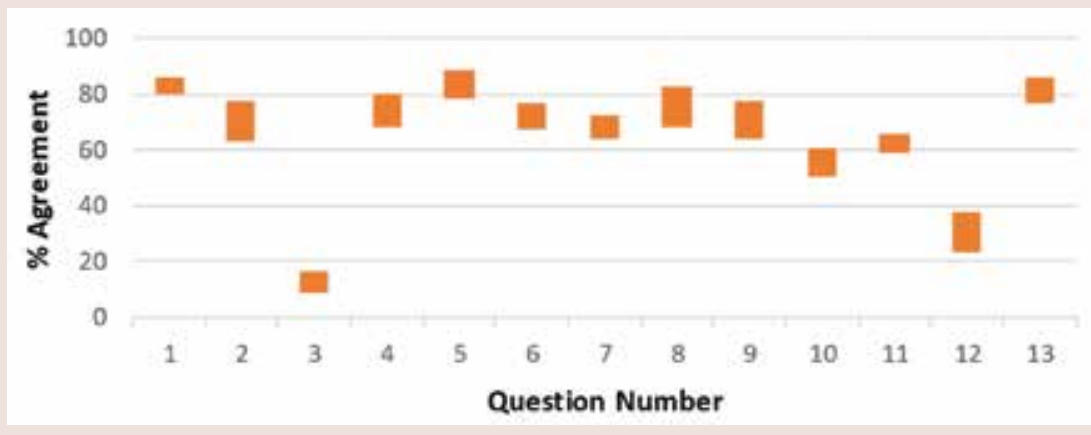

FIGURE 2

Range in percentages of students who agreed or strongly agreed on "engagement" questions across five courses $(N=1,614)$.

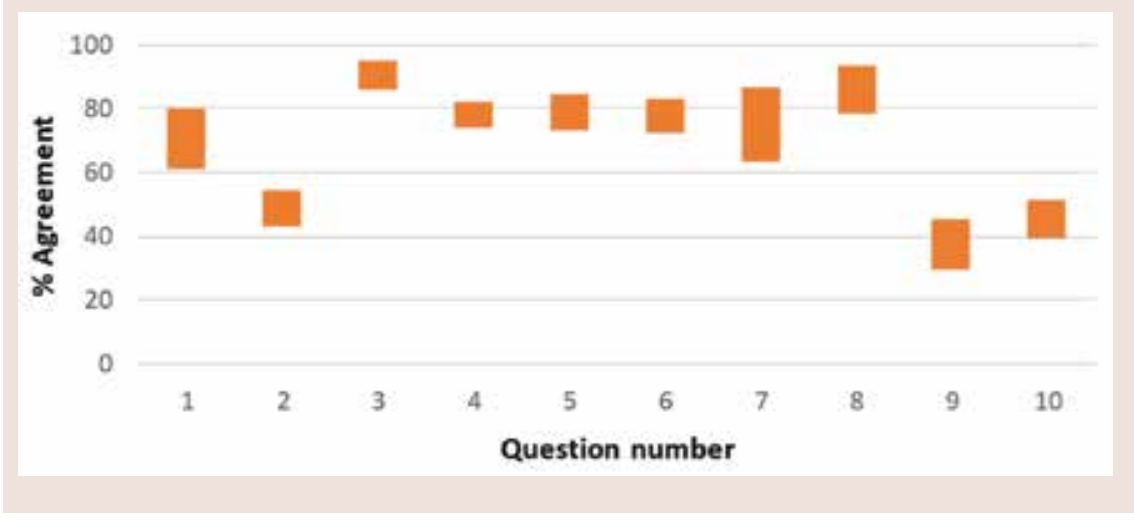

us provide students with deliberate practice in class and makes even our large lectures more communal and informative experiences. In essence, using clickers is a way to have a conversation with our multitudes of students. This interaction can enhance students' motivation. For example, some of us find that even without the grading incentive, students stay after class to explain and debate the answers.

Students reported on the CRiSP questionnaire that the ways we used clicker questions motivated them and promoted their attention, engagement, and participation in class. Students recognized that we used clickers to provide practice and feedback, ad- dressing their learning needs in real time. Students were less positive, however, about clickers making class more enjoyable. Many students also admitted that they often chose the answer to clicker questions without really understanding. Although the idea of student enjoyment is complex, these two responses taken together may reflect one of the advantages in using clickers that students may not fully appreciate - the value in testing oneself. Passive participation in lecture can mislead students into a false sense of competency. Although exposing their ignorance may not always be enjoyable (as their responses suggest), it is a critical step in their learning. 
Using clickers can catalyze pedagogical change at research universities (Koenig, 2010; Kolikant, Drane, \& Calkins, 2010; Vicens \& Caspersen, 2014). In this article we shared the variety of ways that we use clickers to promote deliberate practice in large science courses. Even given the differences in our approaches, the majority of our students perceived that our use of clicker questions helped engage them and enhanced their learning. These examples can help instructors as they transition from a traditional classroom to a more active one, and as they design activities to develop student expertise.

\section{Acknowledgment}

We gratefully acknowledge the advice of Liz Stanwyck in statistical analysis of data.

\section{References}

Bruff, D. (2009). Teaching with classroom response systems: Creating active learning environments. San Francisco, CA: Jossey-Bass.

Caldwell, J. E. (2007). Clickers in the large classroom: Current research and best-practice tips. $C B E-$ Life Sciences Education, 6, 9-20.

Castillo-Manzano, J. I., Castro-Nuño, M., López-Valpuesta, L., SanzDíaz, M. T., \& Yñiguez, R. (2016). Measuring the effect of ARS on academic performance: A global meta-analysis. Computers \& Education, 96, 109-121.

Chien, Y-T., Chang, Y-H., \& Chang, C-Y. (2016). Do we click in the right way? A meta-analytic review of clicker-integrated instruction. Educational Research Review, 17, 1-18.

Dallimore, E. J., Hertenstein, J. H., \& Platt, M. B. (2013). Impact of cold-calling on student voluntary participation. Journal of Management Education, 37, 305-341.

Deslauriers, L., Schelew, E., \& Wieman, C. (2011). Improved learning in a large-enrollment physics class. Science, 332, 862-864.
Eddy, S. L., Brownell. S. E., \& Wenderoth, M. P. (2014). Gender gaps in achievement and participation in multiple introductory biology classrooms. CBE-Life Science Education, 13, 478-492.

Ericsson, K. A., Krampe, R. T., \& Tesch-Römer, C. (1993). The role of deliberate practice in the acquisition of expert performance. Psychological Review, 100, 363-406.

Freeman, S., O'Connor, E., Parks, J. W., Cunningham, M., Hurley, D., Haak, D., ... Wenderoth, M. P. (2007).

Prescribed active learning increases performance in introductory biology. CBE-Life Sciences Education, 6, 132-139.

Goacher, R. E., Moore, D., Sanchez, L., Schupp, P. R., \& Tong, Y. (2015). Using clickers in science, technology, engineering, and mathematics. In D. S. Goldstein \& P. D. Wallis (Eds.), Clickers in the classroom: Using classroom response systems to increase student learning ( $\mathrm{pp}$. 53-69). Sterling, VA: Stylus.

Hodges, L. C., Anderson, E. C., Carpenter, T. S., Cui, L., Gierasch, T. M., Leupen, S., . . W Wagner, C. R. (2015). Using reading quizzes in science classes - the what, why, and how. Journal of College Science Teaching, 45(1), 49-55.

Hunsu, N. J., Adesope, O., \& Bayley, D. J. (2016). A meta-analysis of the effects of audience response systems (clicker-based technologies) on cognition and affect. Computers \& Education, 94, 102-119.

Jones, S. J., Crandall, J., Vogler, J. S., \& Robinson, D. H. (2013). Classroom response systems facilitate student accountability, readiness, and learning. Journal of Educational Computing Research, 49, 155-171.

Koenig, K. (2010). Building acceptance for pedagogical reform through wide-scale implementation of clickers. Journal of College Science Teaching, 39(3), 46-50.

Kolikant, Y. B.-D., Drane, D., \& Calkins, S. (2010). "Clickers" as catalysts for transformation of teachers. College Teaching, 58, 127-135.

Liu, C., Chen, S., Chi, C., Chien, K.-P., Liu, Y., \& Chou, T.-L. (2016). The effects of clickers with different teaching strategies. Journal of Educational Computing Research, 55, 603-628.

MacArthur, J. (2013). How will classroom response systems "cross the chasm"? Journal of Chemical Education, 90, 273-275.

Mazur, E. (1997). Peer instruction: A user's manual. Upper Saddle River, NJ: Prentice Hall.

Meehan, K. C., \& Salmun, H. (2016). Integrating technology in today's undergraduate classrooms: A look at students' perspectives. Journal of College Science Teaching, 46(1), 39-47.

Richardson, A. M., Dunn, P. K., McDonald, C., \& Oprescu, F. (2015). CRiSP: An instrument for assessing student perceptions of classroom response systems. Journal of Science Education and Technology, 24, 432-447.

Schunk, D. H. (1991). Self-efficacy and academic motivation. Educational Psychologist, 26, 207-231.

Vicens, Q., \& Caspersen, M. E. (2014). Getting more scientists to revamp teaching. Journal of College Science Teaching, 43(5), 22-27.

Wieman, C., \& Gilbert, S. (2015). Taking a scientific approach to science education, Part I-research. Microbe, 10, 152-156.

Linda C. Hodges (Ihodges@umbc.edu) is director of the Faculty Development Center, Eric C. Anderson is a senior lecturer in the Physics Department, Tara S. Carpenter is a senior lecturer in the Chemistry and Biochemistry Department, Lili Cui is a senior lecturer in the Physics Department, Elizabeth A. Feeser is a lecturer in the Department of Biological Sciences, and Tiffany Malinky Gierasch is a senior lecturer in the Department of Chemistry and Biochemistry, all at the University of Maryland Baltimore County. 